\title{
Using a Task Based Program Taught through the Discussion Method to Improve Secondary Stage Students' Argumentative Paragraph Writing Skills and Self-Steam
}

\author{
By \\ Dr. Esraa Ramadan El Sayed \\ A Lecturer of curriculum and methods of teaching English \\ Hurghada Faculty of Education \\ South Valley University \\ esraasayed@yahoo.com
}


Using a Task Based Program Taught through the Discussion Method to Improve Secondary Stage Students' Argumentative Paragraph Writing Skills and Self-Steam. Dr. Esraa Ramadan El Sayed

\title{
Using a Task Based Program Taught through the Discussion Method to Improve Secondary Stage Students' Argumentative Paragraph Writing Skills and Self-Steam
}

\author{
By \\ Dr. Esraa Ramadan El Sayed
}

A Lecturer of curriculum and methods of teaching English

Hurghada Faculty of Education

South Valley University

esraasayed@yahoo.com

\section{Abstract :}

The present study was conducted to investigate the effectiveness of using a task based program taught through the discussion method to improve secondary stage students' argumentative paragraph writing skills and self-steam. Ninety two students were randomly selected and divided into a control group and an experimental one. The experimental group was trained in a task based program taught through the discussion method. The control group was instructed a course of these skills through the conventional method of teaching. Instruments of the present study included an argumentative paragraph writing skills test and a self-steam scale. Analysis of data obtained on the post tests revealed that the experimental group surpassed the control group in both the argumentative paragraph writing skills test and the self-steam scale. The suggested training program was found very effective in improving the students argumentative paragraph writing skills and it was found very effective in positively improving the students' self-steam.

Key words: task based program, argumentative paragraph writing skills, students' self-steam 
Using a Task Based Program Taught through the Discussion Method to Improve Secondary Stage Students' Argumentative Paragraph Writing Skills and Self-Steam. Dr. Esraa Ramadan El Sayed

\title{
استخلام برنامج مستنل على المهام في تنمية مهارات كتابة الفقرة \\ الجدلية وتقلير اللذات للدى طلاب المرحلة الثانوبة
}

إعداد

\author{
د/ إسراء روضاز السبد إبراهيبم \\ مدرس المناهج وطرق تدريس اللغة الإنجليزية

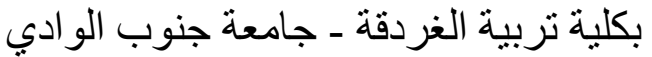 \\ esraasayed@yahoo.com
}

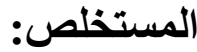

إن الهدف من الدراسة الحالية هو تحديد فاعلية استخدام برنـامج مستتن على المهام في تتمية مهـار ات كتابـة الفقرة الجدليـة وتقدير الذات لدى طـلاب المرحلـة الثانويـة ، و قد شارك إثنان و تسعون من طالبات الفرقة الثانية بالغردقة ، حيث تلقت هذه المجمو عـة تدريباً مبنياً برنامج مُعد بطريقة المهام في تتمية اكتساب مهار ات كتابـة الفقرة الجدلية، و خضعت المجمو عة لاختبار قبلي و بعدي لاختبار كتابـة الفقرة الجدليـة بالإنجليزيـة و مقياس تقدير الذات، و اشارت النتائج إلى أن هنالك تحسن ملحوظ في مهار ات طلاب المجمو عة التجريبية مقارنـةً بطـلاب المجمو عـة الضـابطة في المهار ات الكتابيـة للفقرة الجدلية و كذلك تحسنا ملحوظا في تقدير الذات لدي الطالبات.

الكلمات المفتاحية برنامج مستند على المهام ، مهار ات كتابة الفقرة الجدلية، تقدير الذات لدى الطلاب 
Using a Task Based Program Taught through the Discussion Method to Improve Secondary Stage Students' Argumentative Paragraph Writing Skills and Self-Steam. Dr. Esraa Ramadan El Sayed

\section{Introduction}

Language is used as a means of communication; and thoughts can be expressed in oral as well as in written forms. Thoughts can be easily understood if the language used is understandable, well-developed and within their command. Sometimes an individual may use a language comprehensible to another individual, yet there may be failure in communication. This failure may be due to illogical justifications, ambiguous sentences, misuse of precise words, and irrelevant sentences. A successful communication occurs when the message is fairly delivered. Unity and clarity of thoughts are important factors to achieve sound and mutual understanding.

Writing is an essential element of language. Any curriculum must think about the multidimensional nature of writing in language development as well as evaluation procedures. EFL instructors should give more attention to enhance their learners writing skills. Improving several skills of EFL learners' writing can help in enhancing students expressive written materials.

The ability to write well can have a profound impact on our lives. Writing can be ab art, but it is the task of the artist to create the masterpiece. Without the competency and practice of basic writing skills, neither proficient works of writing art can be fictional nor can any lives be influenced (Currier, 2008).

Hand et al (2007:34) states that: "you can have the greatest technical skills in the world, but without solid communication skills, who will know and who can understand?" this raises a concern about the development of EFL instructions from oral conversations to written prose. 
Disputes among people may arise because of the various and different ideas and principles adopted by people. Although, in any culture, language is the tool through which individuals share their ideas, many conflicts and disputes arise because of mutual misunderstanding. To avoid such disputes, people are constantly trying to become acquainted with other people's ideas and principles. Logical argument, tolerance of opposing views and mutual respect among individuals and countries would surely lead to mutual understanding; and consequently, would help avoid disputes.

Darwish (1999:33) confirms that regardless of the language used, many people are interested in delivering arguments either in a spoken or a written form, but they are even more interested in what lies behind the skill of arguing. They are frequently led to argue with others about adopted ideas, thoughts, and principles.

The ability to argue; in any language; can not be achieved through teaching learners separate words or terms. Rather, it is the proper use of well-arranged and relevant sentences in a reasonable order.

Although the ability to reason is an ability that marks off human from animal intelligence, the opportunities for applying such a skill in our schools and colleges are not enough. This is clear from the sort of errors in reasoning that occur most often in ordinary language. Therefore; mastering the skills of logical reasoning provides us with

a very useful skill, viz., the ability to evaluate and construct justifications of claims.

Learners of English as a foreign language need as many opportunities as possible to be familiar with the possible ways of expressing their points of view and make themselves clearly understood in the foreign language. This can be achieved through adequate training in logical reasoning. 
Because writing is a complex process, learners of English as a foreign language may run into trouble when they attempt writing. Yet, they can benefit from approaching the task of writing in a systematic way. With the help of task - based process, learners make use of what they already know and what they can already do... Furthermore; White (1992:7) shows that the focus on task means that neither the process nor the outcome is predetermined. Flowerdew (1990:327) confirms that, "Task-based approaches to language learning are now very much a part of general English."

Although written argumentative paragraphs in English may not be used outside the classrooms; ( in a way similar to that of the English native speaker ) ; by Egyptian students, argumentative paragraphs enable the learners to be trained to reason logically and adequately. As all human beings should acquire the ability to argue without fighting, to reason by giving logical justifications. Hurghada female second year secondary school students in particular are in need of such skills to help them in their future careers.

It is necessary to emphasize the acquisition of English through instruction that encourages task-based learning centered upon themes. That is because "If students are actively engaged in meaningful, related theme - based tasks, they gain repeated exposure to language that helps them to process the language." White $(1992: 7)$

Strong writing skills may enhance students' chances for success (Alexander, 2008). So, the present research tries to improve EFL youth learners' (Secondary Stage) argumentative paragraph writing skills in order to help them express their opinions. Also, teaching such professional writing skills may give them opportunity to use EFL in their 
Using a Task Based Program Taught through the Discussion Method to Improve Secondary Stage Students' Argumentative Paragraph Writing Skills and Self-Steam. Dr. Esraa Ramadan El Sayed

real life as an actual language not just a language they learn only at school.

One of the most important problems is that a big number of Egyptian EFL learners can not communicate and handle English after graduation. Most of them deal with English as an academic subject. They study it mainly for examinations and success here means better scores that would help them enter the college they dream of. Improving their argumentative paragraph writing skills may affect their test scores as well as teaching them how to express their opinions which is necessary to convey their knowledge.

Reichelt (2009) evaluates critically the writing teaching programs in different foreign language settings. The study called for using more complex types of writing such as critical and argumentative writings in order to develop EFL learners' fluency. The evaluation showed that most EFL writing teaching programs give more attention to basic writing skills even with high levels learners.

The current research is considered a response to Reichelt (2009), as a task based program will help secondary stage students develop their argumentative paragraph writing skills which may affect their self-steam afterwards.

Many studies investigated the nature of argumentative writing and searched for different methods and ways for developing such type of writing. Advances in technology, changes in communication practices, and the imperatives of the workplace have led to the responsitioning of the role of writing in the global context. This has implications for the teaching of writing in schools.

Dornbrack\& Dixon (2014) focuses on the argumentative essay, which is a high-stakes genre. The

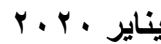
$-7-$

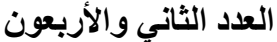


Using a Task Based Program Taught through the Discussion Method to Improve Secondary Stage Students' Argumentative Paragraph Writing Skills and Self-Steam. Dr. Esraa Ramadan El Sayed

results showed that social and school capital are insufficient without explicit instruction of the conventions of this complex genre. It called for extra training programs to develop learners' ability to use such types of writing - argumentative writing - in their written masterpieces.

Helwa (2014) aims in her study to investigate the effectiveness of a program based on the combination of relevance and confidence motivational strategies in developing EFL argumentative writing skills and overcoming writing apprehension among student teachers at a Faculty of education. The researcher used two groups: an experimental group and a control group. Results of the study reveled a statistically significant difference between the mean score of the experimental group and that of the control group in the post test of EFL argumentative writing skills in favor of the experimental group who were taught through a program based on the combination of relevance and confidence motivational strategies. Also, students' writing apprehension was decreased. These results mainly were ascribed to the programs and a variety of techniques, approaches and strategies for developing EFL argumentative writing skills in the Egyptian educational environment.

Mirzaii (2012b) states that "writing as a skill requires language learners to master a number of complex, rhetorical, linguistic, and mechanical conventions" (P.140). Accordingly, Richards and Schimdt (2010) introduce four types of non-creative writing modes which are: descriptive, narrative, expository and argumentative writing, maintaining that a tacit 
Using a Task Based Program Taught through the Discussion Method to Improve Secondary Stage Students' Argumentative Paragraph Writing Skills and Self-Steam. Dr. Esraa Ramadan El Sayed

consensus among EFL/ESL writing instructors is that writers should begin with the simplest mode. The descriptive essay - and gradually move towards learning the most complex one, the argumentative mode.

They also give a clear definition for argumentative writing that "attempts to support a controversial point of defend a position on which there is a difference of opinion "(P337).

With the help of a task-based, process oriented program, students may be encouraged to write freely and use as many words in meaningful sentences as possible. Students may also be encouraged and trained to make a plan for writing their paragraphs.

About academic English arguments, Leki (1989:233) states that a writer can arrange his/her argument in several ways. One way is to state one's opinion and then explain the defense of that point of view step by step. That is a deductive approach. He/she might also use an inductive arrangement, in which he/she reviews the reasons step by step that lead to a conclusion. A writer presents the conclusion after giving the reasons that led him/her to it. In the deductive approach, one begins with his generalization and continues with his supporting evidence. In the inductive approach, a writer begins with his/her evidence and leads the reader up to the generalization. In addition, in an inductive argument, the evidence usually is arranged so that the most convincing evidence comes toward the end, somewhere near the generalization.

Reviewing the studies dealing with writing as a process showed how writing as a process differs from writing as product. Some studies were concerned with skills of argumentative paragraph writing. Others dealt with designing 
Using a Task Based Program Taught through the Discussion Method to Improve Secondary Stage Students' Argumentative Paragraph Writing Skills and Self-Steam. Dr. Esraa Ramadan El Sayed

programs and suggested certain approaches and techniques for developing the writings of the students.

Developments in TEFL and studies conducted in the field of EFL modified and redefined the original aims and methods of teaching writing. The learner's needs have become the central objective in the area of EFL.

Task-based language teaching is an approach that seeks to provide learners with natural contexts for language use. While learners work to accomplish a task, they have many opportunities to interact, communicate and exchange ideas with others. Such skills are thought to facilitate language acquisition as learners have to work in order to understand each other and to express their own meaning and ideas (Larsen - Freeman 2000).

Over the past 20 years, proposals for task Bsed Language Teaching (TBLT) have drawn on a variety of claims about - and prompted further research into processes thought to enhance successful language acquisition. A number of important contributions to Task Based Learning research regarding these claims have appeared in language learning through this period.

According to Branden (2016), Task Based learning has been propagated by some national governments (like Zealand and Vietnam) as the most favored approach to both second and foreign language teaching contexts. International conferences are devoted to this particular 
Using a Task Based Program Taught through the Discussion Method to Improve Secondary Stage Students' Argumentative Paragraph Writing Skills and Self-Steam. Dr. Esraa Ramadan El Sayed

approach, task based syllabuses are being developed in a growing number of educational settings and tasks are used by researchers in studies exploring the processes that drive second and foreign language acquisition. Task based learning was suggested as an important and vital approach in language teaching and it was suggested to be used to develop different language skills.

At the same year, Lee (2016) indicated in her study that task based learning activities fostered learner autonomy in different ways. Structured tasks enabled students to work independently to create content, whereas open - ended tasks allowed them to be more freedom in exploring and understanding of a particular topic through social interaction.

One of the most critical problems in teaching and learning English language is the lack of adequate language background to carry out tasks required. Results of Poonpon (2017) revealed how the interdisciplinary Task Based projects should be implemented in a language classroom to enhance the learners' English language skills.

The similarity between the studies reviewed in the present study lies in dealing with writing as a process, on stated objectives and on identifying the skills of argumentative writing. However, the present study is different from these studies as it used a different approach. It investigates the acquisition and use of more than one aspect of the language. In addition, the present study suggests a program which is 
Using a Task Based Program Taught through the Discussion Method to Improve Secondary Stage Students' Argumentative Paragraph Writing Skills and Self-Steam. Dr. Esraa Ramadan El Sayed

based on the actual needs of the students. Moreover, it is experimental rather than descriptive.

Hisken (2011) and Khansir and Abdolahi (2014) indicate that teachers are aware of the levels of self-esteem, their students can develop activities and lessons that lead to success. Students with a positive self-esteem have been shown to have higher levels of reading skills, as well as a higher level of academic achievement. Students with low self-esteem struggle with problems they face in school. If students have a high level of self-esteem, they will be as successful as possible. They do not spend much time worrying about the way they are viewed by their peers. They focus on their learning more than how they are seen by their peers.

Brown (2000) stated that self-esteem is involved in student's writing and oral performance. Also, he defines self-esteem as the evaluation that individuals make and maintain with regard to themselves, expresses an attitude of approval or disapproval and indicates the extent to which individuals believe themselves to be capable, significant, successful and worthy. Thus, self-esteem has three dimensions; global self-esteem, situational self-esteem and task self-esteem. Global self-esteem is general or prevailing assessment one makes of one's own worth over time and across a number of situations. It focuses on students' personal judgment towards themselves which always exist in their daily activity. Situational self-esteem is one's selfappraisals in particular life situations such as social interaction. Task self-esteem is the self-esteem that relates to particular tasks within specific situations. It refers to one's self-evaluation of a particular aspect of the process. 
Using a Task Based Program Taught through the Discussion Method to Improve Secondary Stage Students' Argumentative Paragraph Writing Skills and Self-Steam. Dr. Esraa Ramadan El Sayed

Majority of EFL instructors introduce such types of writing - argumentative writing - to their students in the same manner as when instructing other writing modes, i.e., narrative, descriptive, or expository. From previous literature, argumentative writing mode needs so many elements that suit its nature like giving evidence and fostering higher skills like critical thinking and persuasion.

From the above, one can conclude that the present study has incorporated skills from the teaching of writing as a process and of the task-based approach in teaching the skills of argumentative paragraphs This, hopefully, has contributed to the effectiveness of the program based on the previously mentioned approaches.

\section{The Problem of The Study}

Although secondary stage students need to develop their ability to write argumentative paragraphs in English, they are not actually trained to do so. The researcher, in a pilot study, invited 20 Hurghada female second year secondary school students to write down a ten sentence argumentative paragraph (See Appendix A). Only two students could write few relevant ideas. Most of the students were poor at writing. Even when they write, the sentences were either incomplete or illogical. In addition to spelling mistakes, errors in grammar, and in cohesive ties were many. The students lack the ability to write well argumentatively. The present study attempted to investigate the effectiveness of using a task based program taught through the discussion method to improve secondary stage students' argumentative paragraph writing skills and self-steam. More specifically, the study tries to answer the following questions:

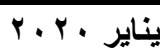

$-13-$

العدد الثاني والأربعون 
1- How far will a task-based, process-oriented training program be effective in improving Hurghada secondary stage students' argumentative paragraph writing skills ?

2- How far will a task-based, process-oriented training program be effective in improving Hurghada secondary stage students' self-steam?

\section{Objectives of The Study}

The present study was conducted to answer all the previously stated questions. Specifically:

1- To identify the effectiveness of using a task based program taught through the discussion method to improve secondary stage students' argumentative paragraph writing skills.

2- To identify the effectiveness of using a task based program taught through the discussion method to improve secondary stage students' self-steam

\section{Hypotheses of the study}

1- There are significant differences (favoring the experimental

group) between means of scores obtained by the subjects of the experimental group and those of the control group in the post - performance on the argumentative paragraph writing skills test.

2- There are significant differences (favoring the experimental

group) between means of scores obtained by the subjects of the experimental group and those of the control group in the post - performance on the self-steam scale. 


\section{Significance of the study}

It is hoped that the program used in this study will help Hurghada secondary stage students improve their argumentative paragraph writing that depends on logical reasoning. Regardless of the language taught, logical reasoning is a skill required in their future professions. It is also hoped that the program of the present study will improve the participants' self-steam and will be a practical model for other secondary school teachers who still use traditional methods of teaching of the writing skill. Furthermore, it is hoped that course designers could use it as a theoretical basis for planning and organizing the materials of EFL in order to satisfy the needs of secondary school students in this respect.

\section{Delimitations of the study}

1-The participants of the study were ninety two Hurghada secondary stage students. Thus, the results would be applicable to this population and to similar populations.

2- Rhetorical skills were delimited to the acquisition and use of the

components of argumentative paragraph writing : claim, evidence and concluding sentence.

3- Lexical skills are not within the scope of the present study.

4- Grammatical skills are limited to the acquisition and use of some grammatical points that are frequently found in

English

argumentative paragraphs.

\section{Definitions of Terms}

Task : Nunan (1989:10) states that a task is " a piece of classroom work which involves learners in comprehending, manipulating, producing or interacting in the target language

العدد الثاني والأربعون


while their attention is principally focused on meaning rather than form." In the present study, the term "task" refers to any goal - driven activity with a specific role for both the teacher and the students.

\section{Material and Method}

The present study was conducted in the Hurghada secondary school and lasted for nine weeks, two hours a week. This duration was enough to cover teaching the units of the program prepared by the researcher. Post-Acquisition, and Post-Use Tests were administered at the end of teaching the program each at a time.

Design of the Experiment

The present study used a pre-test and a post-test design. A treatment and a non-treatment group were exposed to pre-post means of getting data. The treatment group only was instructed and trained through a task-based, process, oriented program in skills of written argumentative paragraphs.

\section{(1) The procedure followed in teaching the experimental group:}

The experimental group was trained through the program of task-based, process oriented approach. The experimental treatment was conducted through the following phases :
a) Lesson presentation
b) Input with instructions
c) Task-based activities
d) Exercises
e) Formative evaluation after each lesson F) Summative evaluation after each unit

Each lesson was introduced through the following steps:

1- Objectives of the lesson were discussed with the students in no more than two minutes. 
Using a Task Based Program Taught through the Discussion Method to Improve Secondary Stage Students' Argumentative Paragraph Writing Skills and Self-Steam. Dr. Esraa Ramadan El Sayed

2- Relevant information and input were introduced. Input was either written on the board or delivered to the students on handouts prepared in advance.

3- After explaining the way of carrying out a task for achieving a given objective of a lesson, the students were divided into groups of eight to nine. Only one group of students was ten. 4- Model examples were illustrated for the students to show them how to participate in a task.

5- A task or more was used to help the students achieve these objectives.

6- Students were invited to take notes whenever possible.

7- The teacher was always a helper, a facilitator, and

sometimes a sharer of ideas and information. He is not a mistake catcher.

8- Paragraph components were taught through

process-oriented, task-based approach. Jigsaw task, filling in task, recognition task, guided writing task, and role play task were used.

9- Before paragraph writing, sometimes a claim was left written on the board for two minutes to challenge the students' thoughts and after that they were divided into groups with different ideas that were either for or against that claim. During writing brain storming was encouraged and revision was highlighted.

10- terms and collocations were illustrated through word lists, mind-maps(concept maps), and tables.

11- Grammatical skills were taught through : describing routine action task, describing chain action task and overlay contrast.

12- Students were invited to do a formative evaluation after each lesson and summative evaluation after each unit . 13- Owing to the process of exchanging of ideas during group work, many times noise occurred and was allowed among the students

(2) Procedures followed in teaching the control group :

العدد الثاني والأربعون


Using a Task Based Program Taught through the Discussion Method to Improve Secondary Stage Students' Argumentative Paragraph Writing Skills and Self-Steam. Dr. Esraa Ramadan El Sayed

\section{The traditional method in teaching writing skills to the control group}

\section{was used as follows:}

a) A topic of an argumentative nature was provided by the teacher and the students were asked to choose a standpoint to write on.

b) The teacher divided the students into two groups and asked each group to elicit a leader .

c) The teacher wrote two opposing claims (of the chosen topic) on the two sides of the board. Each claim suits one group of students

d) Students were asked to write a paragraph supporting their claim by giving all possible and relevant reasons.

e) The teacher explained the difficult terms on the board.

f) The teacher explained the grammatical skills needed by the students.

The researcher taught the grammatical skills by :

1) Explaining grammar rules.

2) Identifying and correcting grammar errors in paragraph writing samples.

3) Doing exercises based on errors noted in the students' writing.

4) Doing sentence -combining exercises.

g) After the students wrote their paragraphs, the researcher identified and corrected the common errors and mistakes committed.

h) The researcher provided the students with a sample of one of the students' paragraphs.

i) The researcher provided the students with model English

argumentative paragraphs and explained the concepts behind their skills.

j) The students were asked to rewrite their paragraphs as an assignment at home.

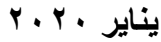

$-18-$

العدد الثاني والأربعون - ان 
Using a Task Based Program Taught through the Discussion Method to Improve Secondary Stage Students' Argumentative Paragraph Writing Skills and Self-Steam. Dr. Esraa Ramadan El Sayed

k) Time spent with the control group was the same as with the experimental group.

- Teacher:

The researcher had to teach both the experimental and the control groups. If another language teacher was invited to teach, it would be difficult to guarantee the effect of factors such as time, work facilities, experience and qualifications on the results of the study.

\section{Variables:}

1- The independent variable is:

- Using a task-based, process oriented training program in argumentative writing

2- The dependent variables are :

a- Students' acquisition of rhetorical and grammatical skills of argumentative paragraphs.

b- Students' use of the rhetorical and grammatical skills of argumentative paragraphs.

3- Control variables are :

The following variables were controlled to achieve homogeneity

of groups :

a- Sex : The study included 92 female second year secondary school students. (46 females were involved in each group)

b- Grade and Years of studying English :

All subjects were Hurghada secondary students. They studied English as a foreign language and they were nearly of the same linguistic background.

d- Pre test data on the acquisition and use tests of rhetorical and grammatical skills of argumentative paragraph was obtained to ensure group equivalence. 
Using a Task Based Program Taught through the Discussion Method to Improve Secondary Stage Students' Argumentative Paragraph Writing Skills and Self-Steam. Dr. Esraa Ramadan El Sayed

Materials \& Instruments of the Study and pre-testing

Each one of the following instruments will be described later on:

\section{1- A training program in argumentative writing designed by the researcher (student book and teacher's guide book )}

- Designing The Program: See Appendix (B)

The objectives of the program reflected the needs of the learners. Ordering was guided by learner needs. Therefore; a task- based, process - oriented approach is the basis in designing the tasks of the program. As the students' needs are the basis of the program, the content has to be chosen on that basis. Activity types involve processes such as information sharing and interaction. The learner gives and takes information. The teacher's role is mainly Facilitator, Counselor and Process Manager. The material is authentic, and promotes communicative language use.

\section{Building the program:}

Building the program progressed through the following steps:

a) Content of the program: The program consists of two units representing argumentative paragraph writing skills. Unit one deals with the rhetorical skills; unit two deals with the grammatical skills.

b) Stating the objectives of the program: They include the rhetorical and grammatical skills of English argumentative paragraph.

c) Content specifications of tasks: Tasks are devised to help achieve the stated objectives.

d) Evaluation : It includes lesson evaluation and unit evaluation.

Validity of The Program :

The program was submitted to a panel of twelve experts in the field of TEFL to decide on the appropriateness of the

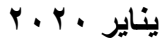
-20 العدد الثاني والأربعون 
program for the subjects of the study, whether behavioral objectives belong to the general goals of the program, fitness of the material presented and tasks designed to the objectives set for each session, and on the applicability and fitness for the group of the study.

According to the advice presented by some jury members, evaluation exercises of the program were simplified, a glossary of the most frequent terms used in authentic texts was enclosed at the end of the program, and some of the behavioral objectives were restated. Other observations of the members of the jury were also taken into consideration. The program was judged to be valid for training Hurghada secondary students on the argumentative paragraph writing skills.

\section{2 - An acquisition test on the rhetorical and} grammatical skills of argumentative written paragraphs developed by the researcher: see Appendix $(C)$ Construction of The Acquisition Test: The acquisition test consists of two parts. These parts represent the specific objectives of the program. The acquisition test includes two sub-tests : a) A sub-test of the rhetorical skills consisting of 10 items. b) A sub-test of the grammatical skills consisting of 20 items.

Scoring of The Acquisition Test: See Appendix (C)

A score is simply the total number of correctly marked answers. Four points are given for each test item. Maximum score for the acquisition test is [120] points.

The Pre test data obtained on the acquisition sub-tests of rhetorical and grammatical skills showed that there were no significant differences between the control and the experimental groups as the t-values shown in Tables 1, and 2 for the acquisition sub-tests were 0.611 and 0.65 respectively insignificant at .05 level.

العدد الثاني والأربعون


Using a Task Based Program Taught through the Discussion Method to Improve Secondary Stage Students' Argumentative Paragraph Writing Skills and Self-Steam. Dr. Esraa Ramadan El Sayed

Means, standard deviations, t-value of means and significance

of differences of the experimental and control groups in the Pre-

testing performance on the acquisition sub-test of rhetorical skills of argumentative paragraphs

\begin{tabular}{l|c|c|c|c|c}
\hline Group & $\begin{array}{c}\text { Number } \\
\text { of } \\
\text { Subjects }\end{array}$ & Means & $\begin{array}{c}\text { Standard } \\
\text { Deviation }\end{array}$ & $\begin{array}{c}\text { Degree } \\
\text { Of } \\
\text { Freedom }\end{array}$ & "t" \\
value
\end{tabular}

Maximum score on the acquisition sub- test of rhetorical skills $=30$

\section{Table (2)}

Means, standard deviations, t-value of means and significance of differences of the experimental and control groups in the Pre- testing performance on the sub-test of the grammatical skills of argumentative paragraphs

\begin{tabular}{l|c|c|c|c|c}
\hline Group & $\begin{array}{c}\text { Number } \\
\text { of } \\
\text { Subjects }\end{array}$ & Means & $\begin{array}{c}\text { Standard } \\
\text { Deviation }\end{array}$ & $\begin{array}{c}\text { Degree } \\
\text { Of } \\
\text { Freedom }\end{array}$ & "t" \\
value
\end{tabular}

Maximum score on the acquisition sub-test of grammatical skills $=80$

4- A use test on the rhetorical and grammatical skills of argumentative written paragraphs developed by the researcher.

\section{Construction of The Use Test}

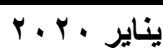

$-22-$

العدد الثاني والأربعون 
Using a Task Based Program Taught through the Discussion Method to Improve Secondary Stage Students' Argumentative Paragraph Writing Skills and Self-Steam. Dr. Esraa Ramadan El Sayed

The use test consists of two parts.Two parts represent the specific

objectives of the program. The use test includes two sub-tests:

a) A sub-test of the rhetorical skills consisting of 10 items.

b) A sub-test of the grammatical skills consisting of 20 items.

Scoring of The Use Test : A score is simply the total number of correctly marked answers. Four points are given for each test item. Maximum score for the use test is [120] points.

Validity and Reliability of The Tests :

Validity and reliability of both tests were estimated through the following procedures;

A pilot study was conducted about a month prior to the administration of the program to estimate validity and reliability of tests. A group of 20 second year female secondary school students was selected.

\section{A- Content Validity of the tests}

Each of the two tests included representative samples of the desired learning outcomes. This was supported by a jury of twelve members that supported the suitability of the tests to the level of the subjects, behavioral objectives and content of the program "the validity of a test is the extent to which the test measures what it is intended to measure" ; Harrison (1983: 11)

\section{B- Reliability of the tests:}

The reliability of each test was determined by the split-half method. Then, Spearman-Brown formula was used in data obtained on tests. Harrison (1983:11) states that, "Reliability means the consistency with which a test measures the same thing all the time". Student's score should be the same or nearly the same over time. For the acquisition test, reliability co-efficient was (0.75).For the use test, it was $(0.70)$

\section{Practicality of the tests:}

العدد الثاني والأربعون


Using a Task Based Program Taught through the Discussion Method to Improve Secondary Stage Students' Argumentative Paragraph Writing Skills and Self-Steam. Dr. Esraa Ramadan El Sayed

Practicality of the tests was assured by the reports of the jury members in this respect. The jury mentioned that the tests were planned appropriately to test specific points and that they are within the students' language level. Also, they pointed that the time allotted for these tests was enough.

\section{Items Analysis}

After scoring the tests, item analysis was done to evaluate the effectiveness of the items. This provided information concerning each of the following points: 1- Index of difficulty 2- Index of discrimination

At the same time, the Pre test data obtained on the use test of rhetorical and grammatical skills showed that there were no significant differences between the control and the experimental groups as the t-values shown in Tables 3 and 4 for the use sub-tests were 0.950 and 0.819 respectively insignificant at .05 level.

\section{Table (3)}

Means, standard deviations, t-value of means and significance of differences of the experimental and control groups in the Pre-testing performance on the sub-test of the use of rhetorical skills of argumentative paragraphs

\begin{tabular}{l|c|c|c|c|c}
\hline Group & $\begin{array}{c}\text { Number } \\
\text { of } \\
\text { Subjects }\end{array}$ & Means & $\begin{array}{c}\text { Standard } \\
\text { Deviation }\end{array}$ & $\begin{array}{c}\text { Degree } \\
\text { Of } \\
\text { Freedom }\end{array}$ & $\begin{array}{c}\text { } \mathrm{t} \text { " } \\
\text { value }\end{array}$ \\
\hline Exp. & 46 & 8.28 & 3.25 & 90 & 0.95 \\
Cont. & 46 & 8.89 & 2.81 & & \\
\hline
\end{tabular}

Maximum score on the use sub- test of rhetorical skills $=40$

Table (4)

Y. r.

$-24-$

العدد الثاني والأربعون 
Using a Task Based Program Taught through the Discussion Method to Improve Secondary Stage Students' Argumentative Paragraph Writing Skills and Self-Steam. Dr. Esraa Ramadan El Sayed

Means, standard deviations, t-value of means and significance of differences of the experimental and control groups in the Pre- testing performance on the sub-test of the Use of grammatical skills in argumentative paragraphs

\begin{tabular}{l|c|c|c|c|c}
\hline Group & $\begin{array}{c}\text { Number } \\
\text { of } \\
\text { Subjects }\end{array}$ & Means & $\begin{array}{c}\text { Standard } \\
\text { Deviation }\end{array}$ & $\begin{array}{c}\text { Degree } \\
\text { Of } \\
\text { Freedom }\end{array}$ & "t" \\
value
\end{tabular}

Maximum score on the use sub- test of grammatical skills $=80$

The experimental group and the control one had the same number of, male and female students; and there were no intervening variables. Therefore, t-test analysis was used to test the hypotheses of the study concerning the significant differences between the control group and the experimental group on post testing of the acquisition and use of argumentative skills.

\section{An EFL Self-Esteem Scale: See Appendix (D)}

The researcher adopted an EFL self-esteem scale based on Rosenberg's standardized questionnaire of self-esteem to account for the degree of self-esteem among foreign language learners. It consists of twenty (20) items. There is no right answer for any statement. The best answer is what they feel is true of themselves. Items are statements to which students respond are $(1=$ not at all ,2 = a little bit, $3=$ somewhat , $4=$ very much, $5=$ extremely).

\section{Findings}

\section{Hypothesis (1) :}

The first hypothesis predicted that the experimental group would surpass the control group in the postperformance on the acquisition sub-test of the rhetorical skills of argumentative paragraph writing.

العدد الثاني والأربعون


Using a Task Based Program Taught through the Discussion Method to Improve Secondary Stage Students' Argumentative Paragraph Writing Skills and Self-Steam. Dr. Esraa Ramadan El Sayed

Analysis of data using "t"- test showed that the experimental group achieved significantly higher scores than the control group on the post acquisition sub-test of rhetorical skills, since "t"-value (8.354) is significant at(.01) level and beyond.

Table ( 5 ) presents a summary of the analysis of post-testing data obtained on the acquisition sub-test

\section{Table (5)}

Means, standard deviations, t-value of means and significance of differences of the control and experimental groups in the post performance on the acquisition sub-test of rhetorical skills of argumentative paragraphs

\begin{tabular}{c|c|c|c|c|c}
\hline Group & $\begin{array}{c}\text { Number } \\
\text { of } \\
\text { Subjects }\end{array}$ & Means & $\begin{array}{c}\text { Standard } \\
\text { Deviation }\end{array}$ & $\begin{array}{c}\text { Degree } \\
\text { Of } \\
\text { Freedom }\end{array}$ & " $\mathrm{t}$ " \\
value
\end{tabular}

Analyzing data using the "t"-test of significance showed a significant difference favoring the experimental group post performance on the pre-post sub-test of the acquisition of rhetorical skills where the experimental group in the post testing achieved a higher significant degree of improvement than on pre-testing. The obtained "t"-value 14.70 is significant at . 01 level and beyond. On the other hand, the control group achieved significant improvement as the "t"-value (7.495) is significant at (.05) level. But the achievement level of the experimental group is significantly higher. See Table (6)

العدد الثاني والأربعون


Using a Task Based Program Taught through the Discussion Method to Improve Secondary Stage Students' Argumentative Paragraph Writing Skills and Self-Steam. Dr. Esraa Ramadan El Sayed

Means, standard deviations, t-value of means and significance of differences of the experimental and control groups in the Pre-post performance on the acquisition subtest of rhetorical skills of argumentative paragraphs

\begin{tabular}{l|c|c|c|c|c}
\hline Group & $\begin{array}{c}\text { Number } \\
\text { of } \\
\text { Subjects }\end{array}$ & Means & $\begin{array}{c}\text { Standard } \\
\text { Deviation }\end{array}$ & $\begin{array}{c}\text { Degree } \\
\text { Of } \\
\text { Freedom }\end{array}$ & $\begin{array}{c}\text { "t" } \\
\text { value }\end{array}$ \\
\hline Pre / exp. & 46 & 11.19 & 3.21 & 90 & $\left(^{*}\right)$ \\
Post / exp. & 46 & 22.74 & 4.18 & 3.71 \\
\hline Pre / cont. & 46 & 10.78 & 3.21 & 90 & $\left({ }^{*}\right)$ \\
Post / cont. & 46 & 16.02 & 3.42 & & 7.50 \\
\hline
\end{tabular}

The experimental group surpassed the control group in the acquisition sub-test of the rhetorical skills of argumentative paragraph writing. This result may be attributed to the probability that the program has improved the students' awareness of the knowledge behind a argumentative paragraph writing. Dealing with writing as a process helped to improve the students' knowledge of these rhetorical skills. Moreover, this result shows the students' positive involvement in the activities of the tasks.

On the other hand, we cannot neglect the improvement achieved by the control group students. On basis of these results, learning the rhetorical skills through task -based approach was effective in helping students acquire these rhetorical skills.

Hypothesis (3):

The third hypothesis predicted that the experimental group would surpass the control group in the post-performance on the acquisition sub-test of the grammatical skills of argumentative paragraph writing. Analysis of data obtained using " $\mathrm{t}$ "- test showed that the 
Using a Task Based Program Taught through the Discussion Method to Improve Secondary Stage Students' Argumentative Paragraph Writing Skills and Self-Steam. Dr. Esraa Ramadan El Sayed

experimental group achieved significantly high scores than the control group on the acquisition sub-test of grammatical skills, since "t"-value (4.87) is significant at (.01) level.

Table (7) introduces a summary of the analysis of post-testing data obtained on the acquisition sub-test

\section{Table (7)}

Means, standard deviations, $t$-value of means and significance

of differences of the control and experimental groups in the post

performance on the acquisition of grammatical skills of argumentative paragraphs

\begin{tabular}{c|c|c|c|c|c}
\hline Group & $\begin{array}{c}\text { Number } \\
\text { of } \\
\text { Subjects }\end{array}$ & Means & $\begin{array}{c}\text { Standard } \\
\text { Deviation }\end{array}$ & $\begin{array}{c}\text { Degree } \\
\text { Of } \\
\text { Freedom }\end{array}$ & "t" \\
value
\end{tabular}

Maximum Score $=80$

Comparison of the results of the experimental group on the pre-post sub-test of the acquisition of grammatical skills showed that the experimental group in the post testing achieved a higher significant degree of improvement than on pre-testing. The obtained "t"-value (9.29) is significant at (. 01) level and beyond.

On the other hand, the control group achieved significant improvement as the "t"-value (6.14) was significant at (.01) level and beyond. Table (9) shows these results.

\section{Table ( 9 )}

Means, standard deviations, t-value of means and significance

of differences of the experimental and control groups in the Pre- 
Using a Task Based Program Taught through the Discussion Method to Improve Secondary Stage Students' Argumentative Paragraph Writing Skills and Self-Steam. Dr. Esraa Ramadan El Sayed

post performance on the acquisition sub-test of grammatical

skills of argumentative paragraphs

\begin{tabular}{c|c|c|c|c|c}
\hline Group & $\begin{array}{c}\text { Number } \\
\text { of } \\
\text { Subjects }\end{array}$ & Means & $\begin{array}{c}\text { Standard } \\
\text { Deviation }\end{array}$ & $\begin{array}{c}\text { Degree } \\
\text { Of } \\
\text { Freedom }\end{array}$ & "t" \\
value
\end{tabular}

Maximum Score $=80$

The experimental group surpassed the control group in the acquisition sub-test of the grammatical skills of argumentative paragraph writing. This result may be attributed to many factors: a) The program has improved the students' awareness of the knowledge of the grammatical skills of an argumentative paragraph. b) The students found the tasks enjoyable. c)The target tasks provided frequent examples that facilitated the students' acquisition.

On the other hand, there is a slight improvement achieved by the control group students. On basis of these results, learning grammatical skills through task -based approach was effective in helping students acquire grammatical skills.

\section{Hypothesis 4:}

The fourth hypothesis predicted that the experimental group would surpass the control group in the post-performance on the use sub-test of the rhetorical skills of argumentative paragraph writing. Analysis of data obtained using "t"- test showed that the experimental group achieved significantly higher scores than the control group

العدد الثاني والأربعون


Using a Task Based Program Taught through the Discussion Method to Improve Secondary Stage Students' Argumentative Paragraph Writing Skills and Self-Steam. Dr. Esraa Ramadan El Sayed

on the use sub-test of rhetorical skills, since "t"-value (13.96) is significant at .01 level and beyond. This means that learning rhetorical skills through task-based approach was effective in helping students use these rhetorical skills.

Table ( 9 ) presents a summary of the analysis of post-testing data obtained on the use sub-test.

Table ( 9 )

Means, standard deviations, $t$-value of means and significance

of differences of the control and experimental groups in the post-

performance on the use sub-test of rhetorical skills of argumentative paragraphs

\begin{tabular}{r|c|c|c|c|c}
\hline Group & $\begin{array}{c}\text { Number } \\
\text { of } \\
\text { Subjects }\end{array}$ & Means & $\begin{array}{c}\text { Standard } \\
\text { Deviation }\end{array}$ & $\begin{array}{c}\text { Degree } \\
\text { Of } \\
\text { Freedom }\end{array}$ & $\begin{array}{c}\text { "t" } \\
\text { value }\end{array}$ \\
\hline Post/ cont. & 46 & 13.59 & 1.88 & 90 & $\left(^{*}\right)$ \\
Post/ exp. & 46 & 19.87 & 2.36 & & 13.96 \\
\hline
\end{tabular}

Maximum Score $=27$

Comparison of the results of the experimental group on the pre-post sub-test of the use of rhetorical skills showed that the experimental group in the post testing achieved a higher significant degree of improvement than on pre-testing. The obtained "t"-value (19.342) is significant at ( . 01 ) level and beyond.

On the other hand, the control group achieved significant improvement as the "t"-value (9.32) was significant at ( . 01) level and beyond. These results are shown in Table (11).

Table ( 10 )

Means, standard deviations, t-value of means and significance

العدد الثاني والأربعون


Using a Task Based Program Taught through the Discussion Method to Improve Secondary Stage Students' Argumentative Paragraph Writing Skills and Self-Steam. Dr. Esraa Ramadan El Sayed

of differences of the experimental and control groups in the Pre-

post performance on the Use sub-test of rhetorical skills of argumentative paragraphs

\begin{tabular}{|c|c|c|c|c|c|}
\hline Group & $\begin{array}{c}\text { Number } \\
\text { of } \\
\text { Subjects }\end{array}$ & Means & $\begin{array}{l}\text { Standard } \\
\text { Deviation }\end{array}$ & $\begin{array}{l}\text { Degree } \\
\text { Of } \\
\text { Freedom }\end{array}$ & $\begin{array}{c}\text { "t" } \\
\text { value }\end{array}$ \\
\hline $\begin{array}{l}\text { Pre / exp. } \\
\text { Post / exp. }\end{array}$ & $\begin{array}{l}46 \\
46\end{array}$ & $\begin{array}{l}8.28 \\
19.87\end{array}$ & $\begin{array}{l}3.25 \\
2.36\end{array}$ & 90 & $\begin{array}{c}\left({ }^{*}\right) \\
19.34\end{array}$ \\
\hline $\begin{array}{l}\text { Pre / cont. } \\
\text { Post / cont. }\end{array}$ & $\begin{array}{l}46 \\
46\end{array}$ & $\begin{array}{l}8.89 \\
13.59\end{array}$ & $\begin{array}{l}2.81 \\
1.88\end{array}$ & 90 & $\begin{array}{c}\left({ }^{*}\right) \\
9.32\end{array}$ \\
\hline
\end{tabular}

The experimental group surpassed the control group in the use sub-test of the rhetorical skills of argumentative paragraph writing. This result may be attributed to a variety of reasons ; dealing with writing as a process in the program has improved the students' ability to use the rhetorical skills of argumentative paragraph writing. Besides, the frequent use of court-like situations and the students' interest in and enjoyment of expressing themselves freely without being afraid of making errors have contributed to this improvement. The result may explain that stating a claim, outlining and writing evidence, and deciding a final judgment are almost properly written. Consequently, this has improved the students' ability to organize and write logical argumentative paragraphs.

\section{Hypothesis 6:}

The sixth hypothesis predicted that the experimental group would surpass the control group in the post-performance on the use sub-test of the grammatical skills of argumentative paragraph writing. Analysis of data obtained using " $\mathrm{t}$ "- test 
Using a Task Based Program Taught through the Discussion Method to Improve Secondary Stage Students' Argumentative Paragraph Writing Skills and Self-Steam. Dr. Esraa Ramadan El Sayed

showed that the experimental group achieved significantly higher scores than the control group on the use sub-test of grammatical skills, since "t"-value (10.52) is significant at (.01) level and beyond .

Table (11) introduces a summary of the analysis of post-testing data obtained on the use sub-test

\section{Table (11)}

Means, standard deviations, t-value of means and significance

of differences of the control and experimental groups in the post-

performance on the use of the sub-test of grammatical skills of

argumentative paragraphs

\begin{tabular}{c|c|c|c|c|c}
\hline Group & $\begin{array}{c}\text { Number } \\
\text { of } \\
\text { Subjects }\end{array}$ & Means & $\begin{array}{c}\text { Standard } \\
\text { Deviation }\end{array}$ & $\begin{array}{c}\text { Degree } \\
\text { Of } \\
\text { Freedom }\end{array}$ & $\begin{array}{c}\text { "t" } \\
\text { value }\end{array}$ \\
\hline Post/ cont. & 46 & 30.59 & 4.24 & 90 & $\left.{ }^{*}\right)$ \\
Post/ exp. & 46 & 43.98 & 7.42 & & 10.52 \\
\hline
\end{tabular}

Maximum Score $=66$

Comparison of the results of the experimental group on the pre-post sub-test of the use of grammatical skills showed that the experimental group in the post testing achieved a higher significant degree of improvement than on pre-testing. The obtained "t"-value (22.99) is significant at ( . 01 ) level and beyond.

On the other hand, the control group achieved significant improvement as the " $t$ "-value (17.72) was significant at ( . 01) level and beyond. These results are shown in Table (12) .

العدد الثاني والأربعون


Using a Task Based Program Taught through the Discussion Method to Improve Secondary Stage Students' Argumentative Paragraph Writing Skills and Self-Steam. Dr. Esraa Ramadan El Sayed

\section{Table (12)}

Means, standard deviations, t-value of means and significance of

differences of the experimental and control groups in the Pre- post

performance on the use sub-test of grammatical skills of argumentative paragraphs

\begin{tabular}{c|c|c|c|c|c}
\hline Group & $\begin{array}{c}\text { Number } \\
\text { of } \\
\text { Subjects }\end{array}$ & Means & $\begin{array}{c}\text { Standard } \\
\text { Deviation }\end{array}$ & $\begin{array}{c}\text { Degree } \\
\text { Of } \\
\text { Freedom }\end{array}$ & "t" \\
value
\end{tabular}

The experimental group surpassed the control group in the use sub-test of the grammatical skills of argumentative paragraph writing. This result may be due to the effect of the program which has improved the students' ability to use the grammatical skills of argumentative paragraph writing. It could be due to the fact that the tasks used in this area were relevant to the students' personal experiences which, in turn, have led the students to positively involve in the activities of the tasks. The result may confirm the idea that the students enjoyed being involved in the grammatical tasks without being afraid of making mistakes. Consequently, the students' ability to use these grammatical skills in writing argumentative paragraphs has improved

It was evident that the students' argumentative writing skills, their cooperation to write and their improved 
Using a Task Based Program Taught through the Discussion Method to Improve Secondary Stage Students' Argumentative Paragraph Writing Skills and Self-Steam. Dr. Esraa Ramadan El Sayed

self-esteem significantly improved due to the use of using a task based program taught through the discussion method .

\section{Discussion}

The results of the present study emphasize that training students to acquire and use rhetorical and grammatical skills of argumentative paragraph writing through a task-based, process-oriented program was effective in helping the students acquire and use these skills and in improving their ability to write argumentative paragraphs. Moreover, while supervising the experimental group, it was observed that there was an element of competition among the members of the group; they wanted to share in the tasks correctly; they tried to guess new points, ideas, and answers. Tasks could provide interesting chances of participation. Authentic English texts could also provide vivid material for many real cases. Students were seriously defending their standpoints.

The teacher's role helped the students of the experimental group to be always active and serious. Being among students, the teacher, sometimes reminded the class of the task at hand. He was always giving instructions, help, encouragement and feedback. Further, he invited the class to trust the value of their participation. The teacher used to deal with the students' errors as a healthy part of the teaching and learning process. Correction of mistakes and errors was done selectively. The classroom has become a place in which students could find trust, respect, encouragement and joy. Students not only learned the language when they participated in talking, listening and writing, but also gained insights into the feelings and lives of their classmates as well as themselves. Generally, the results of the present study shows that the experimental group students have almost properly learned (acquired / used) the skills of argumentative paragraphs; and that the 
Using a Task Based Program Taught through the Discussion Method to Improve Secondary Stage Students' Argumentative Paragraph Writing Skills and Self-Steam. Dr. Esraa Ramadan El Sayed

tasks used were very helpful and effective in achieving this objective.

On the other hand, using the traditional method (product-oriented) in teaching the English course-as observed during supervising the control group - has led the teacher to talk almost all the time while the students were listening. It was observed that there was much hesitation and long periods of silence. The teacher waited for long periods in silence until he saw the product. The students, fearing of making mistakes, used to avoid real participation in the activities of the lessons. This fear could have been responsible for avoiding participation, or cheating on the part of the students. As a result, the amount of written sentences was significantly less than that of the experimental group. Wood (1993:38) states that "these factors impede language learning." Although the conventional method provided few chances for participation, students were serious in defending their stand points. Yet, they often resorted to Arabic words and structures while forming their English sentences. Therefore, less noise and less co-operation were noticed. In addition, it was also observed that feedback was postponed until work was finished. The instructor used to correct lots and lots of students' errors which were considered an unhealthy sign of learning and that the teacher's time talk was less in the experimental group compared to the control group. The classroom used to be a place in which students listen most of the time to the monotonous orders of the teacher. In spite of the significant results achieved by the students of the control group, it could be concluded that the conventional method was not as effective in its outcome as the task-based, process, oriented approach was.

Generally, it was clear that the students' argumentative writing skills their self-esteem were significantly improved due to the use of the task based program taught through the discussion method.

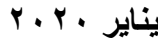

$-35-$

العدد الثاني والأربعون 


\section{Conclusions}

First of all, the present study has obeyed the wind of change in methodology. It supports teaching English writing as "a process", instead of teaching it as "a product". Moreover, the program has been designed to answer the needs of Hurghada female second year secondary school students

Post test data show that after training Hurghada female second year secondary school students in the content of the task-based, process-oriented program, their scores are found to be significantly higher on the post tests than on the pre -tests (Before instruction);a result that points out that tasks did facilitate acquiring and using the rhetorical and grammatical skills of argumentative paragraph writing. Since the training program was built mainly to teach the students the main skills of argumentative paragraph writing, it was found effective.

\section{Suggestions}

It is suggested for the teacher of the suggested program to 1-help the students to deliver all possible relevant ideas in order to convince and argue logically.

2- Break the class into groups of five to six students instead of eight to nine students to have a better participation in group work .

3- Help spark out students' interests by writing a thought -provoking and enjoyable message that may be left (usually on the board) five or ten minutes before the class begins.

\section{Recommendations :}

The following recommendations are considered significant:

العدد الثاني والأربعون


1- Hurghada female second year secondary school students should be trained to discuss debatable topics.

2- Materials and activities prepared for Hurghada female second year secondary school students should go hand in hand with the learners' needs.

3- Hurghada female second year secondary school students should acquire and use the English grammatical rules in appropriate language situations that are relevant to the students' real lives and careers.

\section{Recommendations For Future Research:}

1 -Research is needed to find out the effect of the suggested program of the present study on improving the linguistic ability of the students.

2 -The present study should be replicated using other subjects.

3 -Additional research is needed to study the needs of second, third, and fourth year.

4 -Further research is needed to study the use of authentic English and the effect on the students' writings.

5 -Further research is needed to conduct detailed analysis of authentic argumentative writings.

6 -Further research is needed to study the use of rhetorical questionsand their implications in argumentative writings and their effect on the reader of these writings.

7-More research is called for to study the use of process-oriente writing programs for Hurghada female second year secondary school students.

8- More research is called for scanning lexical of argumentative writing skills. 
Using a Task Based Program Taught through the Discussion Method to Improve Secondary Stage Students' Argumentative Paragraph Writing Skills and Self-Steam. Dr. Esraa Ramadan El Sayed

References :

Abdelwaheed, A. (2014). Using debates to improve secondarystudents'argumentative writing and their attitudes towards English.

Curriculum and instruction department, culture and science, Arab Studies and Research Institute, Arab Organization for Education.

Alexander, M. (2008). Good writing leads to good testing, Retrieved from http://www.stickyminds.com/sitewide. asp?objectid=3391\&fu nction=edetail\&object type=ART Retrieved on April 28, 2016 Ali, Hayat Refaey (1995) . "The Effect of Using A Task-Based Approach on Developing Linguistic and Communicative Competence of 1st Year English Majors in The Faculty of Education , Minia University" : Journal of Research in Education and Psychology, Faculty of Education, Minia University, Vol. 8, No. 3 , January.

Branden, K. (2016). Task - based language teaching. The Routledge handbook of English language teaching, 238-251 Brown, H. D. (2000). Principles of Language Learning and Teaching. New York: Addison Wesley Longman, Inc.

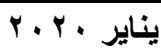
$-38-$ العدد الثاني والأربعون 
Using a Task Based Program Taught through the Discussion Method to Improve Secondary Stage Students' Argumentative Paragraph Writing Skills and Self-Steam. Dr. Esraa Ramadan El Sayed

Currier, D. (2008). Essay on the importance of writing - need feedback please. Asian ESL Journal, 80 (2), 183-199 Dornbrack, J. \& Dixon, K. (2014). Towards a more explicit writing pedagogy: The complexity of teaching argumentative writing. Reading \& Writing Journal of the Reading Association of south Africa, 5 (1), 1-8

Flowerdew, John (1990) . "English for specific purposes---a selective review of Literature" : ELT Journal ,Vol. 44/4 October, Oxford University Press.

Harrison, Andrew (1983) . A Language Testing Handbook . London :The Macmillan Press Ltd.

Helwa, H. (2014). The effectiveness of a program based on the combination of relevance and confidence motivational strategies in developing EFL argumentative writing skills and overcoming writing apprehension among student teachers at Faculty of Education. Benha University, Egypt. (Eric N. ED545646) .

Larsen - Freeman. (2000). Techniques and principles in language teaching. Oxford: Oxford university press.

Lee, L.(2016). Autonomous learning through task basedinstruction in fully online language courses. Language learning \& technology, 20(2), 81-97 
Using a Task Based Program Taught through the Discussion Method to Improve Secondary Stage Students' Argumentative Paragraph Writing Skills and Self-Steam. Dr. Esraa Ramadan El Sayed

Leki , Ilona (1989 ) . Academic Writing : Techniques and Tasks. New York : St. Martin's Press.

Marizaii, M. (2016b). Consciousness - raising instruction and its effect on Iranian EFL learners' use of the mechanics of writing. Iranian EFL Journal, 8 (5), 139-196 PoonPon, K. (2017). Enhancing English language skills through project based learning. The English teacher, XL, $1-10$.

Reichelt, M. (2009). A critical evaluation of writing teaching programmes in different foreign language settings. Writing in Foreign Language Contexts: Learning, Teaching, and Research, 3, 183-206

Richards, J., \& Schmidt, R. (2010). Longman dictionary of language teaching and linguistics (4th ed.). London: Longman (Pearson Education).

White, Ronald V. (1992) . "Academic writing : process and product", ELT Documents 129 , 13 January , Oxford University Press. 